\title{
Validation and improvement of Risk-UE LM2 capacity curves for URM buildings with stiff floors and RC shear walls buildings.
}

\author{
P. Lestuzzi 1), ", S. Podestà ${ }^{2)}$, C. Luchini ${ }^{2)}$, A. Garofano ${ }^{1)}$, D. Kazantzidou-Firtinidou \\ 3), C. Bozzano ${ }^{3)}$ \\ 1) Ecole Polytechnique Fédérale de Lausanne, EPFL-ENAC-IIC-IMAC, Lausanne, Switzerland \\ 2) DICCA, University of Genoa, Genoa, Italy \\ 3) CREALP, Sion, Switzerland
}

Originally published in Bulletin of Earthquake Engineering doi: 10.1007/s10518-016-9981-9

A full-text-view-only version is available at http://rdcu.be/neTO.

\begin{abstract}
This paper addresses seismic vulnerability assessment at an urban scale and more specifically the capacity curves involved for building damage prediction. Standard capacity curves are a function of predefined building typology and are proposed in the Risk-UE LM2 method for computation of the corresponding damage grades. However, these capacity curves have been mainly developed for building stock of southern European cities and the accuracy of their application with different building features, such as the ones of cities of northern Europe should be assessed.

A recent research project of seismic scenarios for the cities of Sion and Martigny in Switzerland provided the opportunity to check the capacity curves of Risk-UE LM2 method. Within the framework of this project, a detailed analysis was achieved for more than 500 buildings. These buildings were typical Swiss buildings and were composed of both unreinforced masonry buildings with stiff floors and reinforced concrete buildings. The construction drawings of each building were collected in order to have the most accurate information about their main structural characteristics. The typological classification that has been adopted was developed in a recent research project. Based on the individual features of the buildings, individual capacity curves were defined.

Results of the seismic assessment applied to the 500 buildings compare very well with those obtained by using Risk-UE LM2 method for unreinforced masonry buildings with stiff floors. A slight improvement may be proposed for buildings with three stories through their introduction to the category of low-rise instead of mid-rise buildings. By contrast, accuracy for reinforced concrete buildings with shear walls is very poor. Damage prediction using related capacity curves of Risk-UE LM2 method does not correspond to reality. Prediction is too pessimistic and moreover damage grades increase with the height category (low-rise, mid-rise and high-rise) of these buildings which is in contradiction with the observed damages for this type of buildings.

Improvements are proposed to increase the accuracy of the seismic vulnerability assessment for northern European building stock. For unreinforced masonry buildings, a slight modification of the limits of the height category of buildings using the ones defined for RC buildings improves the damage prediction. For reinforced concrete buildings with shear walls improved capacity curves derived from the typological curves of the specific typology $C$ are proposed.
\end{abstract}

Keywords : Risk-UE method, seismic vulnerability assessment, existing buildings, capacity curves, damage grades, RC shear walls, URM

\section{Introduction}

Seismic risk analyses at a territorial level are important for both the development of prevention strategies and post-earthquake emergency management. Indeed these analyses, on the basis of exposure and vulnerability data of the built environment, result in an assessment of damage scenarios on a territorial level representative of a possible estimation of damage on the investigated area, as a result of a well-defined seismic event. 
The values proposed in Table 3 correspond to the ones of specific typology $C$ of 3 storey, 6 storey and 8 storey height for RC2_L, RC2_M and RC2_H respectively.

\section{Conclusions}

Standard capacity curves of the Risk-UE LM2 method were checked to validate the accuracy of their application for the computation of the corresponding damage grades in case of seismic vulnerability assessment of cities of northern Europe.

A recent research project of seismic scenarios for the cities of Sion and Martigny in Switzerland provided the opportunity for checking the defined capacity curves of Risk-UE LM2 typologies RC2 and M6-PC. Within the framework of this project, a detailed analysis was achieved for more than 500 typical Swiss buildings composed of both unreinforced masonry buildings with stiff floors and reinforced concrete shear walls buildings. Based on individual features of the buildings, individual capacity curves were first determined and typological curves were developed afterwards using statistical considerations.

The comparison of damage grade related to use of Risk-UE LM2 capacity curves or use of typological curves shows that the results are very similar for unreinforced masonry buildings with stiff floors, i.e. the M6-PC typology. By contrast, accuracy for reinforced concrete buildings with shear walls, i.e. the RC2 typology, is very poor.

As a consequence, seismic vulnerability assessment of cities of northern Europe may be performed adequately using capacity curves of M6-PC typology but use of the capacity curves of RC2 typology should be avoided because the related damage prediction is too much pessimistic. Moreover, the trend of damage grades with respect to building height is in contradiction with observed damages for this type of buildings.

Improvements are proposed to increase the accuracy of the seismic vulnerability assessment using Risk-UE LM2 method for northern European building stock. For unreinforced masonry buildings, i.e. M6-PC typology, a slight modification of building height limit using limits defined for RC buildings improves the damage prediction. Low-rise (M6-PC_L) should include buildings up to 3 storey height, mid-rise (M6-PC_M) should corresponds to buildings between 4 and 7 storey height and high-rise (RC2_H) should start with buildings from 8 storey height. For reinforced concrete buildings with shear walls, i.e. RC2 typology, improved capacity curves derived from the typological curves of the specific typology $C$ are proposed.

However, seismic risk and loss assessment of northern European urban territories may be achieved with even more accuracy using the new typological curves presented in this paper instead of the standard Risk-UE LM2 capacity curves.

\section{Acknowledgments}

The investigations were founded by the canton of Valais, the cities of Sion and Martigny and the Centre de Recherche sur l'Environnement Alpin (CREALP). Authors are grateful to anonymous reviewers for the detailed reviews and comments that significantly improved the quality of the paper. 


\section{References}

[1] FEMA 178. (1997). NEHRP handbook for the seismic evaluation of existing buildings, Federal Emergency Management Agency.

[2] HAZUS. (1999). Earthquake loss estimation methodology - Technical and user manuals, vol. 1-3. Federal Emergency Management Agency (FEMA), National Institute of Building Sciences, Washington, DC.

[3] Otani, S. (2000). Seismic vulnerability assessment methods for buildings in Japan. Earthquake Engineering and Engineering Seismology, Vol. 2, n. 2, pp. 47-56.

[4] Ventura, C.E., Liam Finn, W.D., Onur, T., Blanquera, A., Rezai, M. (2005). Regional seismic risk in British Columbia - Classification of buildings and development of damage probability functions, Can. J. Civ. Eng., Vol. 32, pp. 372-387.

[5] Onur, T., Ventura, C.E., Liam Finn, W.D. (2005). Regional seismic risk in British Columbia - Damage and loss distribution in Victoria and Vancouver. Can. J. Civ. Eng., Vol. 32, pp. 361-371.

[6] Ergunay, O., Gulkan, P. (1991). Seismic risk reduction and disaster management: national report of Turkey. In Proceedings of Workshop on Seismic Risk Reduction and Disaster Management, Roma, Italy, November, 1991.

[7] Benedetti, D., Petrini, V. (1984). On seismic vulnerability of masonry buildings: proposal of an evaluation procedure. L'Industria delle Costruzioni, Vol. 18, pp. 66-78. (in Italian)

[8] GNDT. (1993). Rischio sismico di edifici pubblici - Parte I: aspetti metodologici, Centro Servizi Quasco, Bologna. (in Italian)

[9] Seismocare. (1998). Seismocare Computed Aided Reduction of Seismic Risk with application to existing cities, town planning and construction - Directions to fill in the vulnerability form GNDT levels 1 and 2, European project Environment and Climate, 19941998, ENV4-CT97-0588.

[10] Dolce, M., Masi, A., Marino, M., Vona, M. (2003). Earthquake damage scenarios of the building stock of Potenza (Southern Italy) including site effects. Bulletin of Earthquake Engineering, Vol. 1, pp. 115-140.

[11] Oliveira, C.S. (2003). Seismic vulnerability of historical constructions: a contribution. Bulletin of Earthquake Engineering, Vol.1, n. 1, pp. 37-82.

[12] Roca, A., Goula, X., Susagna, T., Chávez, J., González, M., Reinoso, E. (2006). A simplified method for vulnerability assessment of dwelling buildings and estimation of the damage scenarios in Catalonia (Spain). Bulletin of Earthquake Engineering, Vol.4, n. 2, pp. 141-158.

[13] Guéguen, P., Michel, C., Le Corre, L. (2007). A simplified approach for vulnerability assessment in moderate-to-low seismic hazard regions: application to Grenoble (France). Bulletin of Earthquake Engineering, Vol. 5, n. 3, pp. 467-490.

[14] Lang, K., Bachmann, H. (2003). On the seismic vulnerability of existing unreinforced masonry buildings. Journal of Earthquake Engineering, Vol. 7, n. 3, pp. 407-426. 
[15] Swiss Seismological Service (SED) at ETH Zurich (2015). Swiss National Probabilistic Seismic Hazard Assessment 2015. Zurich: Federal Institute of Technology. (23/05/2016 from http://www.seismo.ethz.ch/prod/Erdbebengefaehrdungsmodell_2015/index_EN)

[16] Greifenhagen C. and Lestuzzi P. (2005). Static-cyclic tests on lightly reinforced concrete shear walls. Engineering Structures. Vol 27/11, pp. 1703-1712.

[17] Risk-UE. (2003). An advanced approach to earthquake risk scenarios with applications to different european towns. Projet Européen, EVK4-CT-2000-00014.

[18] Mouroux, P., Le Brun, B. (2006). Presentation of RISK-UE Project. Bulletin of Earthquake Engineering, Vol. 4, pp. 323-339.

[19] Mouroux, P., Bertrand, E., Bour, M., Le Brun, B., Depinois, S., Masure, P., RISK-UE team (2004). The European RISK-UE Project: an advanced approach to earthquake risk scenarios. 13th World Conference on Earthquake Engineering (WCEE), Vancouver, B.C., Canada, August 1-6, 2004, Paper No. 3329.

[20] Grünthal G., Musson R. M. W., Schwarz J., Stucchi M. (2001). European Macroseismic Scale 1998, EMS-98. Cahiers du Centre Européen de Géodynamique et de Séismologie, Volume 19. ISBN 2-9599804-3-3. Conseil de l'Europe, Luxembourg.

[21] Milutinovic, Z.M., Trendafiloski, G.S. (2003). An advanced approach for earthquake risk scenarios with applications to different European towns. WP-4: Vulnerability of current buildings. Risk-UE Project, European Commission.

[22] Lagomarsino, S., Giovinazzi, S. (2006). Macroseismic and mechanical models for the vulnerability and damage assessment of current buildings. Bulletin of Earthquake Engineering, Vol. 4, pp. 415-443.

[23] Freeman, S.A. (1998). The capacity spectrum method. In: Proc. 11th European conference on earthquake engineering. Paris.

[24] Lestuzzi, P., Podestà, S., Luchini, C., Garofano, A., Kazantzidou-Firtinidou, D., Bozzano, C., Bischof, P., Haffter, A. (2016). Seismic vulnerability assessment at urban scale for two typical Swiss cities using Risk-UE methodology. Natural Hazards. DOI 10.1007/s11069-0162420-z.

[25] SIA 261 (2003, Swiss standard). Actions on structures, Swiss Society of Engineers and Architects (SIA), Zurich 2003.

[26] Kazantzidou-Firtinidou, D., Bozzano, C., Rouiller, J.-D., Lestuzzi, P., Podestà, S., Luchini, C. (2015). Evaluation expéditive de la vulnérabilité sismique du bâti des agglomérations de Sion et Martigny. Projet SEISMOVAL-Risk-UE-UniGEN. Rapport final. CREALP. (in French)

[27] Luchini C. (2016). Development of displacement-based methods for seismic risk assessment of the existing building stock. PhD thesis, University of Genova, Italy, 2016.

[28] Lagomarsino S., Cattari S. (2013). Seismic vulnerability of existing buildings:

Observational and mechanical approaches for application in urban areas - Chapter 1. In: Seismic vulnerability of structures. P. Guéguen (ed.), 1-62. ISTE Ltd and John Wiley and Sons, 2013. 
[29] Fritsche, S., Fäh, D. (2009). The 1946 magnitude 6.1 earthquake in the Valais: siteeffects as contributor to the damage. Swiss Journal of Geosciences, 102(3), pp. 423-439.

[30] Cattari, S., Curti, E., Giovinazzi, S., Lagomarsino, S., Parodi, S., Penna, A. (2004). Un modello meccanico per l'analisi di vulnerabilità del costruito in muratura a scala urbana, Proceedings of XI Convegno Nazionale "L'ingegneria sismica in Italia”, Genova, Italy.

[31] Luchini C., Podestà S. (2015). Sviluppo di modelli meccanici con approccio agli spostamenti per la valutazione della vulnerabilità sismica delle tipologie strutturali svizzere. In: Proc. of $16^{\text {th }}$ Italian Conference on Earthquake Engineering, L'Aquila, Italy. (in Italian)

[32] Crowley, H., Pinho, R., Bommer, J. J. (2004). A probabilistic displacement-based vulnerability assessment procedure for earthquake loss estimation, Bulletin of Earthquake Engineering, vol. 2, no. 2, pp. 173-219

[33] SIA 2018 (2004, Swiss standard). Vérification de la sécurité parasismique des bâtiments existants, Swiss Society of Engineers and Architects (SIA), Zurich, 2004. (in French)

[34] Liel A.B., Haselton C.B., Deierlein G.G., Baker J.W., (2009). Incorporating modeling uncertainties in the assessment of seismic collapse risk of buildings. Structural Safety, Vol. 31, No. 2, pp. 197-211.

[35] Pagnini L.C., Vicente R.S., Lagomarsino S., Varum H., (2011). A mechanical model for the seismic vulnerability assessment of old masonry buildings. Earthquake and Structures. Vol. 2, No. 1, pp. 25-42.

[36] Fajfar P., (1999). Capacity spectrum method based on inelastic demand spectra. Earthquake Engineering and Structural Dynamics, 28:979-993.

[37] Michel C., Lestuzzi P., Lacave C. (2014). Simplified non-linear seismic displacement demand prediction for low period structures. Bulletin of Earthquake Engineering. Vol. 12/4, pp. 1563-1581. 